\title{
A Low Cost Negative Pressure Wound Therapy Based on Arduino
}

\author{
Fikri Fahriansyah $\mathrm{P}^{1}$, Sari Luthfiyah ${ }^{1}$, Triana Rahmawati ${ }^{1}$, Nur Hasanah Ahniar ${ }^{2}$ \\ ${ }^{1}$ Department of Electromedical Engineering Poltekkes Kemenkes Surabaya \\ Jl. Pucang Jajar Timur No. 10, Surabaya, 60245, Indonesia \\ ${ }^{2}$ Department of Electromedical Engineering Poltekkes Kemenkes Jakarta II \\ Jl. Hang Jebat III No. 4, Jakarta Selatan, 12120, Indonesia \\ Email: fikrifahriansyah.ff@gmail.com
}

\begin{tabular}{|c|c|}
\hline Article Info & Abstract \\
\hline $\begin{array}{l}\text { Article History: } \\
\text { Receive Mei 15, } 2020 \\
\text { Revised August 10, } 2020 \\
\text { Received August 30, } 2020\end{array}$ & $\begin{array}{l}\text { One of the causes of increasing diabetes mellitus is irregular diet, lifestyle, and exercise. This } \\
\text { disease can cause complications, including susceptibility to infection, so that it develops into diabetic } \\
\text { ulcers and can lead to amputations. The purpose of this study is to design a low-cost device used to } \\
\text { treat diabetic ulcers. The contribution of this study is that the system can help remove fluid from the } \\
\text { wound with controlled suction pressure so that it can facilitate the healing process faster. This device } \\
\text { is called as negative pressure wound therapy (NPWT) device, which works based on negative pressure }\end{array}$ \\
\hline $\begin{array}{l}\text { Keywords: } \\
\text { Wound } \\
\text { Negative Pressure } \\
\text { MPX } \\
\text { Therapy }\end{array}$ & $\begin{array}{l}\text { from the vacuum motor by utilizing MPXV4115VC6U and MPXV5050VC6T1 pressure sensors at a } \\
\text { pressure limit of } 0 \text { to }-350 \mathrm{mmHg} \text {. Arduino microcontroller was used to process the data from the } \\
\text { sensor. Further, the process data will then be displayed on the liquid crystal display (LCD) for user } \\
\text { communication. The MPX4115VC6U sensor produces a pressure of }-55.97 \mathrm{mmHg} \text { when setting }-50 \\
\mathrm{mmHg} \text {, and the resulting output is } 3.32 \text { volts, while the MPXV5050VC6T1 sensor produces a pressure } \\
\text { of } 51.18 \mathrm{mmHg} \text { at a setting of } 50 \mathrm{mmHg} \text {. The resulting output is } 3.18 \text { volts; from the above data, it can } \\
\text { be seen that the MPX5050VC6TI sensor has a smaller error. }\end{array}$ \\
\hline
\end{tabular}

\section{Corresponding Author:}

Sari Luthfiyah

sariluthfiyah@yahoo.co.id

Department of Electromedical Engineering

Poltekkes Kemenkes, Surabaya
This work is an open access article and licensed under a Creative Commons Attribution-ShareAlike 4.0 International License (CC BY-SA 4.0).

\section{INTRODUCTION}

Negative Pressure Wound Therapy (NPWT) is a result of the sophisticated development of therapeutic methods for wound care procedures. This method worked by using foam dressing and applying negative pressure. In which, these will produce a vacuum effect on the wound area. So that the exudate fluid of the existing diabetic ulcer will be sucked and wasted. This can increase the flow of blood around the wound area smoothly, which results in the formation of granulation tissue the faster and decreased bacterial colonization of the wound, so that the wound healing process can be achieved immediately [1] [2].

Although a variety of materials have been tried for wound care, the use of foam dressings that have pores has proven to be more effective in diabetic ulcers, because it allows the open cell system to create even negative pressure on the wound surface [3][4]. The amount of negative pressure applied to the wound is $50 \mathrm{mmHg}-150 \mathrm{mmHg}$, referring to the clinical user manual of the NPWT PRO tool by the Cardinal Health company. Usually, the negative pressure applied to the wound is $125 \mathrm{mmHg}$ [5][6]. The use of this method is proven safe because it causes wounds to heal quickly and successfully closes, eliminates existing diabetic ulcers in order to minimize the risk of amputation, less likely to get an infection, reduces expenses for treatment, and also shorter hospital stays so that comfort is more temporary obtained by patients will be more optimal [7]. The pattern of life that is instantaneous and also the high level of community ignorance in terms of regulating eating patterns and inappropriate sports schedules, is thought to be one of the causes of the increasing number of Diabetes Mellitus. Understanding Diabetes Mellitus is a chronic metabolic disorder characterized by high levels of sugar in the blood and no significant relationship between intake of vitamins $\mathrm{C}$ and $\mathrm{E}$ on blood sugar levels [8][9]. Complications that can arise from this disease are in the form of excessive susceptibility to infection, so that if left unchecked and not 
handled properly can develop into diabetic ulcers that are very difficult to cure and can even lead to amputations in these parts of the body [10][11][12].

Based on the previous study, it has been made a negative pressure wound therapy (NPWT) in order to accelerate the healing process. In this case, they used Microcontroller-Based [13]. The weakness of the tool is that it still uses a Ball valve so that the selection of input pressures is always felt less subtle. This can cause an uncomfortable effect on the patient during the therapy process. In addition, other complaints are found in the large size of the volume on the Disposable Canister, which is $400 \mathrm{ml}$, as well as the overall design of the device, which is still simple.

Following the literature review, a breast pump was modified as a negative pressure wound therapy to accelerate the healing of Diabetes wounds [14]. The disadvantage of this tool is that there is no display to display the amount of pressure selected, and there is no available setting feature for the duration of therapy, making it less practical in operating the device.

Based on the identification of the problems above, the authors want to design a device for negative pressure wound therapy (NPWT) based on Arduino. Hopefully, this design will help doctors or nurses to carry out treatment easily to accelerate the process of wound healing in patients.

\section{MATERIALS AND METHODS}

\section{A. Experimental Setup}

This study uses a different suction power at each pressure, taking data taken one time to get the results of pressure and voltage measurements.

\section{B. Materials and Device}

This study uses MPXV4115VC6U and MPXV5050VC6T1 sensors to read the results of the pressure released by Vacuum Motor. Arduino is used to processing data read by MPX sensors. Use the $2 \times 16$ LCD as a screen to display the Pressure and Timer values.

\section{Experiment}

In this study, researchers measured the pressure and voltage values between the MPXV4115VC6U sensor [15] and the MPXV5050VC6T1 sensor [16].

\section{The Diagram Block}

The Diagram Block is shown in (Fig 1). The power supply provides voltage to all blocks so that all circuit blocks work. Then in the input block, there is a selection of starters, up, down, stop, which has different functions. The start button is a function to run the commands that have been set. Furthermore, the up and down button is to select the length of time. Moreover, the stop button function to stop the command.

For the process block, there is a microcontroller which functions to control all the circuit blocks. The output of the microcontroller is a driver whose function is to drive the motor after the motor moves; it produces suction power and pressure. A pressure sensor will read the pressure on the tube, and the pressure sensor can be selected using MPXV4115VC6U or MPXV5050VC6T1, the results of the sensor data are processed to the microcontroller after processed then the results of the microcontroller will be displayed on the $2 \times 16$ LCD display.

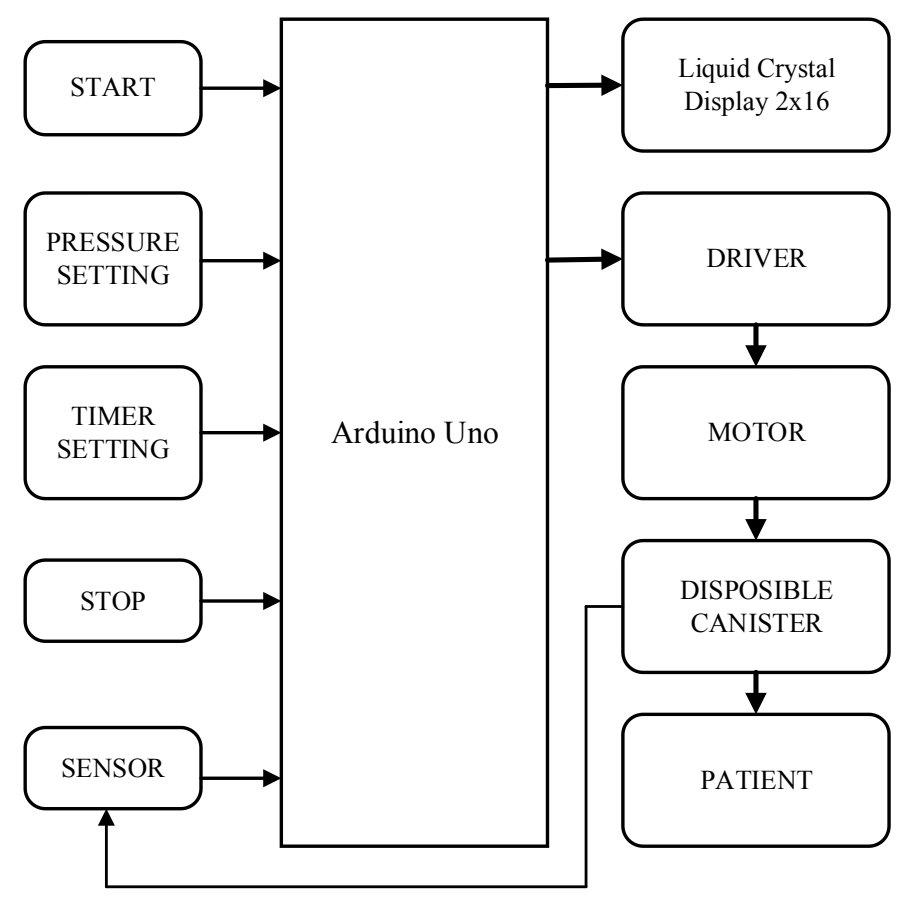

Fig 1. The diagram block system

E. The Flowchart

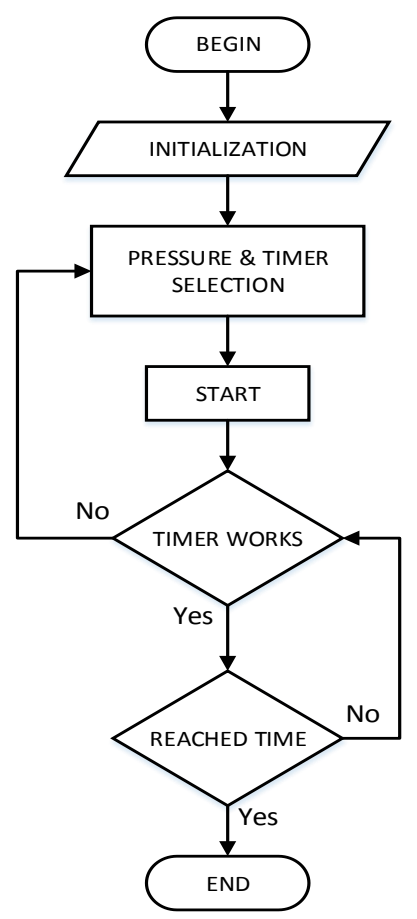

Fig 2. The Flowchart

The flowchart shown in (Fig 2). When the switch is ON then the tool turns on and the next process will start, then press enter 
to make the selection of the sensor to be used, then press enter again to select the pressure level, is at $-50 \mathrm{mmHg}$ to -350 $\mathrm{mmHg}$, when the pressure level is selected then press enter again for the selection of the duration of therapy in the range of 30 minutes to 5 hours using the up and down buttons, then press the enter key to start the timer and motor, so that the motor pump is active. Furthermore, the pump motor will provide negative pressure to the tube, and then the sensor will read the negative pressure on the tube, and the results of the reading from the next sensor are displayed on the LCD. If you want to change the pressure level, select the stop button, then set the pressure level as desired, then enter, the pressure on the pump motor will change according to the pressure chosen, the device will continue to operate during the timer works. The device will stop running when the timer has been reached or by pressing the stop button.

\section{F. Circuit}

\section{1) MPXV4115VC6U Sensor Circuit}

Input in the sensor circuit is pressure; the pressure captured by the sensor is converted to a voltage. In this type of sensor, the ratio of pressure and voltage is directly proportional so that the resulting value is the higher the pressure, the higher the output will be.

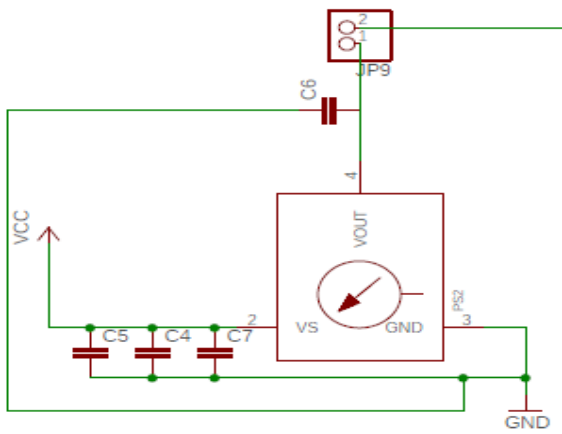

Fig 3. MPXV4115VC6U Sensor Circuit

\section{2) MPXV5050VC6T1 Sensor Circuit}

This sensor also has the same configuration. This circuit worked as follows; the input sensor circuit is pressure, the pressure captured by the sensor will be converted to a voltage. In this type of sensor, the ratio of pressure and voltage is directly proportional so that the resulting value is the higher the pressure, the higher the output results.

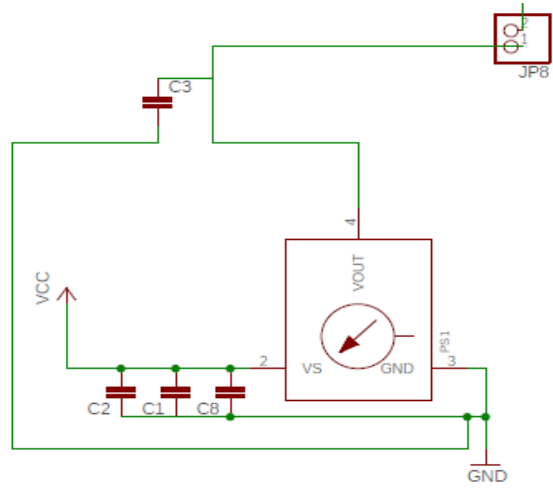

Fig 4. MPXV5050VC6T1 Sensor Circuit

\section{3) Motor Driver Circuit}

The motor in the circuit is controlled using a MOC driver, which is given a PWM signal input to set the duty cycle or when it is on, and when it is dead, MOC here acts as an input gate on the motor.

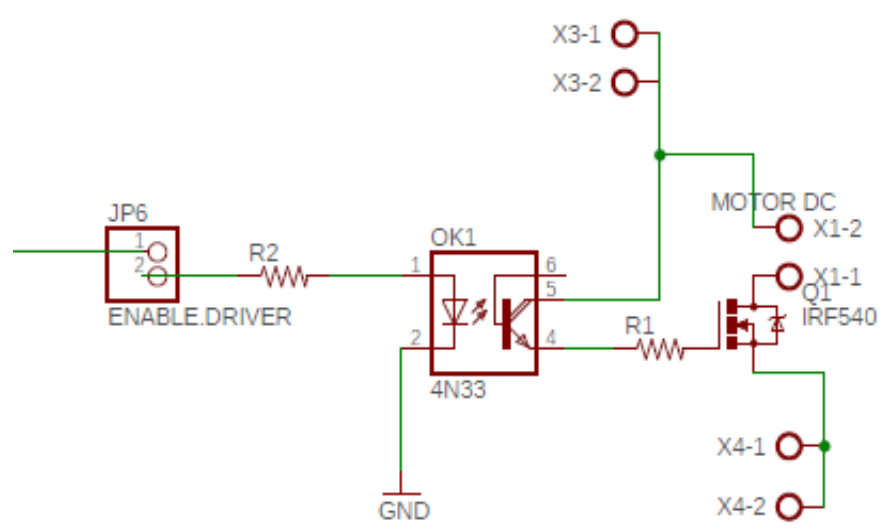

Fig 5. Motor Driver Circuit

\section{4) Selenoid Valve Driver Circuit}

The circuit is used to control the solenoid valve, and the control uses a relay and transistor; if the pressure is met, then the transistor will saturate, resulting in the relay working and the solenoid closing. Diodes in this circuit are mounted parallel to the coil relay so that no reverse flow occurs, which results in relay trilling. 


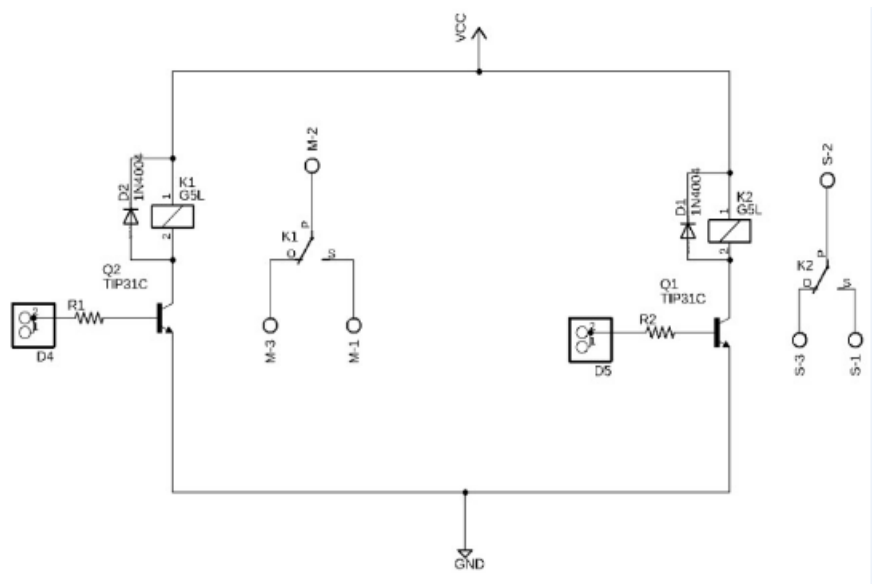

Fig 6. Selenoid Valve Driver Circuit

\section{RESULTS}

\section{A. The design}

In this study, an NPWT design was produced that could be used to suck out fluid in wounds. This system has integrated sensors, suction, and display. This design is shown in Fig. 7.

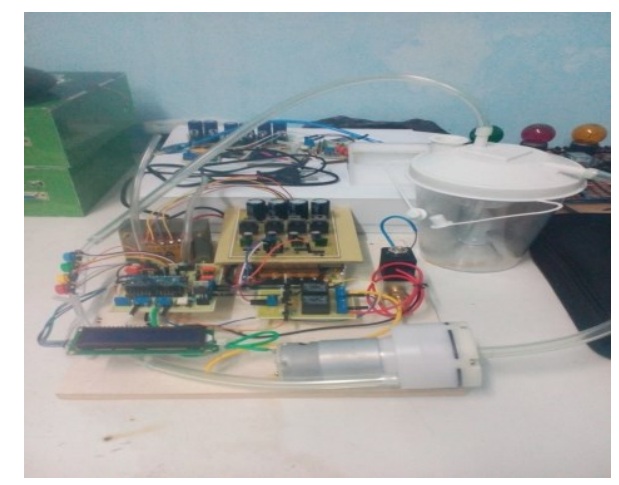

Fig 7. The NPWT design

\section{B. Results of NPWT design}

An illustration of panel design is shown in Fig. 8, which consists of a circuit box, liquid crystal display, user button, and the suction machine.

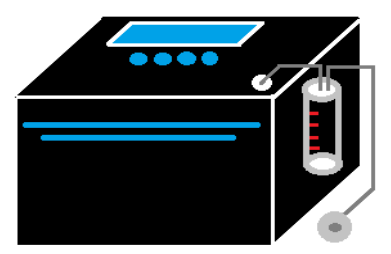

Fig 8. Results of NPWT design
C. Listing program for Sensor Reading

IF (millis() - tsLastReport > mpx) THEN sensorValue $=$ analogRead(A0); sensorValue2 $=$ analogRead(A1); voltage $=($ sensorValue $*($ voltageMax/sensorMax $))$; voltage $2=($ sensorValue $2 *($ voltageMax/sensorMax $)$ ); $\mathrm{p}=(($ voltage -4.54261$) / 0.03826)$; $\mathrm{p} 2=(($ voltage2-4.54261 $) / 0.03826)$; $\mathrm{mmHg} 1=\left(\mathrm{p}^{*} 7.5\right)$; $\operatorname{mmHg} 2=(\mathrm{p} 2 * 7.5)$; $\mathrm{np}=\mathrm{mmHg} 1-\mathrm{nul}$; np2=mmHg2-nul2; ;

IF (np $>=0)$ THEN $\mathrm{np}=0$;

ENDIF

IF (np2>=0) THEN np2 $=0$;

tsLastReport $=$ millis () ;

ENDIF

ENDIF

The program is a conversion calculation on the sensor, and the sensor ADC value will be multiplied by the ratio between the maximum voltage and the maximum sensor value to get the sensor voltage value. The voltage value will be reduced by 4.54261 and divided by 0.03826 to get the p-value. Furthermore, the p-value will be multiplied by 7.5 to get the unit of pressure in $\mathrm{mmHg}$.

D. Program for Pressure Selection

menupt:
WHILE(1)
IF ( $\operatorname{setP}<=-350)$ THEN
setP=-350;
ENDIF
IF (setP $>=-50$ ) THEN
setP=-50;
ENDIF
pmmhg=setP;
lcd.clear();
lcd.setCursor(2, 0);
lcd.print("PILIH TEKANAN");
lcd.setCursor(4, 1);
lcd.print(pmmh);
lcd.setCursor(11, 1);
lcd.print("mmHg");
delay(100);
enter=digitalRead(6);
up=digitalRead(7);
down=digitalRead(8);
IF (enter==HIGH) THEN
delay(200);lcd.clear();goto menupwd;




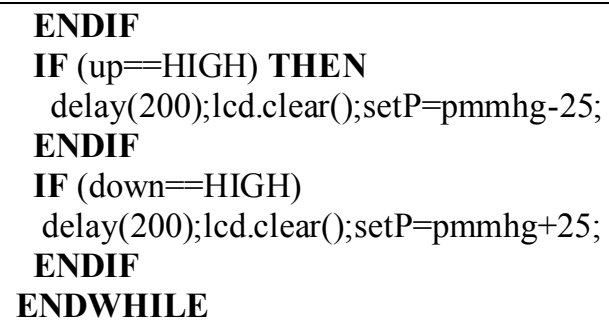

This program will display the selection of pressure values that you want to use by pressing the up button to increase the pressure value and the down button to reduce the pressure value in the range of -50 to $-350 \mathrm{mmHg}$. If the enter key is pressed, it will continue in the time setting.

\section{Listing program for Sensor Selection}

menups:
WHILE(1)
lcd.setCursor(2, 0);
lcd.print(">MPXV4115VC6U<");
lcd.setCursor(2, 1);
lcd.print("MPXV5050VC6T1");
enter=digitalRead(6);
up=digitalRead(7);
down=digitalRead(8);
IF (enter==HIGH) THEN
delay(200);lcd.clear();sen=2;goto menupt;
ENDIF
IF (up==HIGH) THEN
delay(200);lcd.clear();goto menups2;
ENDIF
IF (down==HIGH) THEN
delay(200);lcd.clear();goto menups2;
ENDIF
ENDWHILE
menups2:
delay(200);lcd.clear();sen=1;goto menupt;
WHILE(1)
lcd.setCursor(2, 0);
lcd.print("MPXV4115VC6U");
lcd.setCursor(2, 1);
lcd.print(">MPXV5050VC6T1<");
enter=digitalRead(6);
up=digitalRead(7);
down=digitalRead(8);
IF (enter==HIGH)

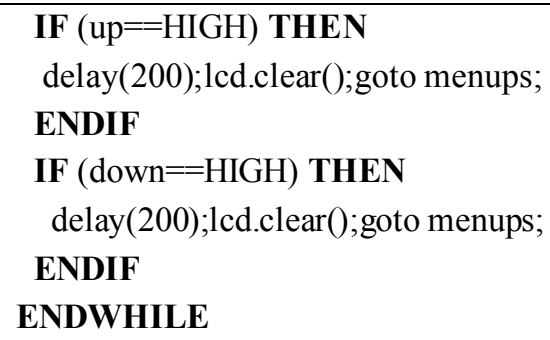

The above program functions as a selection set for sensor one or sensor 2, which will display the selection display on the LCD MPXV4115VC6U and > MPXV5050VC6T1<. By pressing the up and down buttons. If you have chosen, press the enter button to start the pressure selection.

\section{F. Measurement results on the module}

Based on the measurement, as shown in TABLE I, the results obtained in the -50 setting are sensor voltage output value of $3.32 \mathrm{v}$, and the pressure on the module reads -55.97 $\mathrm{mmHg}$. The -75 setting is obtained from a sensor with an output voltage of $3.13 \mathrm{~V}$, and the pressure on the module reads $74.17 \mathrm{mmHg}$. Moreover, the -100 setting is obtained output value of $3.03 \mathrm{~V}$ and the pressure on the module reads -103.88 $\mathrm{mmHg}$; the -125 setting is obtained the sensor voltage output value of $3 \mathrm{v}$ and the pressure at the module reads -125.91 $\mathrm{mmHg}$, the -150 setting is obtained the sensor voltage output value of $2.95 \mathrm{v}$ and the pressure on the module reads -151.78 $\mathrm{mmHg}$.

TABLE I. MEASUREMENT ON MPXV4115VC6U

\begin{tabular}{ccc}
\hline Module Setting & $\begin{array}{c}\text { Sensor Output } \\
\text { Voltage (V) }\end{array}$ & $\begin{array}{c}\text { Pressure On The } \\
\text { Module (mmHg) }\end{array}$ \\
\hline-50 & $3,32 \mathrm{~V}$ & $-55,97$ \\
\hline-75 & $3,13 \mathrm{~V}$ & $-74,17$ \\
\hline-100 & $3,03 \mathrm{~V}$ & $-103,88$ \\
\hline-125 & $3 \mathrm{~V}$ & $-125,91$ \\
\hline-150 & $2,95 \mathrm{~V}$ & $-151,78$ \\
\hline
\end{tabular}

TABLE II. MEASUREMENT ON MPXV5050VC6T1

\begin{tabular}{ccc}
\hline Module Setting & $\begin{array}{c}\text { Sensor Output } \\
\text { Voltage (V) }\end{array}$ & $\begin{array}{c}\text { Pressure On The } \\
\text { Module (mmHg) }\end{array}$ \\
\hline-50 & $3,18 \mathrm{~V}$ & $-51,18$ \\
\hline-75 & $3,10 \mathrm{~V}$ & $-77,05$ \\
\hline-100 & $3,06 \mathrm{~V}$ & $-108,67$ \\
\hline-125 & $2,99 \mathrm{~V}$ & $-124,95$ \\
\hline-150 & $2,93 \mathrm{~V}$ & $-148,91$ \\
\hline
\end{tabular}

Based on the results of measurements on TABLE II. the reading results on the -50 setting are obtained sensor voltage output value of $3.18 \mathrm{v}$ and the pressure on the module reads $51.18 \mathrm{mmHg}$, on the -75 setting is obtained sensor voltage output value of $3.10 \mathrm{v}$ and pressure the module reads -77.05 $\mathrm{mmHg}$, the -100 setting is obtained the sensor voltage output value of $3.06 \mathrm{v}$, and the pressure reads the module -108.67 $\mathrm{mmHg}$, the -125 setting is obtained the sensor voltage output 
value is $2.99 \mathrm{v}$ and the pressure the module reads -124.95 $\mathrm{mmHg}$, the -150 setting is obtained the sensor voltage output value of $2.93 \mathrm{v}$ and the pressure on the module reads -148.91 $\mathrm{mmHg}$.

\section{DISCUSSION}

In this study, researchers measured the amount of pressure and voltage on the MPX sensor when the device was operating; the results obtained turned out to show the difference in each pressure and voltage between the MPXV4115VC6U sensor and MPXV5050VC6T1 sensor. From the measurement results, this device can work well and run according to the timer that has been set. But the weakness of this module is that when it is operating, the pressure that comes out can not be stable according to the limits set.

\section{CONCLUSION}

After making the Arduino-Based Negative Pressure Wound Therapy (NPWT) module, it can generally be concluded that the module can be used but still needs refinement. This can be proven when the module is working can release the vacuum pressure and can approach the pressure that has been set before even though the suction is not stable, and the module can stop working when the timer has been reached.

\section{REFERENCES}

[1] A. M. Kapoor, "Wound Machine Wound Healing Healing Therapy Therapy Machine," 2018 3rd Int. Innov. Appl. Comput. Intell. Power, Energy Control. with their Impact Humanit., pp. 1-5, 2018.

[2] N. Shaheed et al., "Negative Pressure Wound Therapy (NPWT) in open wound management: A study of 16 Cases in Orthopaedic Department of Faridpur Medical College Hospital," Faridpur Med. Coll. J., vol. 7, no. 2, pp. 63-66, 2013.

[3] D. Parducho et al., "Smart wound dressing with arduino microcontroller," 2018 IEEE 10th Int. Conf. Humanoid, Nanotechnology, Inf. Technol. Commun. Control. Environ. Manag. HNICEM 2018, pp. 4-7, 2019.

[4] J. Białecki, P. Pyda, A. Kołodziejska, A. Rybak, and S. Sowier, "Applying NPWT to bleeding open wounds after forefoot amputation in diabetic foot patients - a case report," Negat. Press. Wound Ther. J., vol. 5, no. 4, pp. 5-8, 2018.

[5] R. W. Kartika, "Terapi Ulkus Kaki Diabetes dengan NPWT ( Negative Pressure Wound Therapy )," vol. 45, no. 9, pp. 674-677, 2018.

[6] B. Mrozikiewicz-Rakowska, E. Bucior, J. Kania, A. Nowak, M. Chojnowski, and J. Krzymień, "Modern alternative or first-line treatment: How to safely use Negative Pressure Wound Therapy in Diabetic Foot Syndrome?," Negat. Press. Wound Ther. J., vol. 2, no. 1, pp. 21-25, 2015.

[7] M. S. Timmers, S. Le Cessie, P. Banwell, and G. N. Jukema, "The effects of varying degrees of pressure delivered by negative-pressure wound therapy on skin perfusion," Ann. Plast. Surg., vol. 55, no. 6, pp. 665-671, 2005.

[8] C. Yanuar Dini, M. Sabila, I. Yusuf Habibie, F. Ari Nugroho, and J. Gizi Fakultas Kedokteran Universitas Brawijaya Malang, "Indonesian Journal of Human Nutrition Asupan Vitamin C dan E Tidak
Mempengaruhi Kadar Gula Darah Puasa Pasien DM Tipe 2," Indones. J. Hum. Nutr., vol. 4, pp. 65-78, 2017.

[9] C. Sardella, "One step at a time - making strides toward a solution for the diabetic foot problem," IEEE Pulse, vol. 35, no. june, pp. 18-22, 2014.

[10] R. Kaur, "Negative pressure wound therapy impact on fast recovery in major and minor surgery recovery time," Proc. 2015 Int. Conf. Green Comput. Internet Things, ICGCIoT 2015, pp. 1604-1606, 2016.

[11] Y. Umasankar, "Towards Biosensor Enabled Smart Bandages for Wound Monitoring: Approach and Overview," Proc. IEEE Sensors, vol. 2018-Octob, no. Di, pp. 1-4, 2018.

[12] L. Wang, P. C. Pedersen, D. M. Strong, B. Tulu, E. Agu, and R. Ignotz, "Smartphone-based wound assessment system for patients with diabetes," IEEE Trans. Biomed. Eng., vol. 62, no. 2, pp. 477-488, 2015.

[13] R. Nindyasari, "Rancang bangun NPWT (Negative Pressure Wound Therapy) untuk Mempercepat Penyembuhan Ulkus Diabetik Berbasis Mikrokontroller," p. 2012, 2012.

[14] S. Yunita, S. Saryono, P. Iwan, and H. Hartono, "Modifikasi pompa asi sebagai terapi luka bertekanan negatif untuk mempercepat penyembuhan luka diabetes," J. Ners, vol. 10, no. 1, pp. 104-111, 2015.

[15] F. Semiconductor, "Freescale Semiconductor Integrated Silicon Pressure Sensor On-Chip Signal Conditioned, Temperature Compensated and Calibrated," Sensors (Peterborough, NH), pp. 1-8, 2010.

[16] NXP Semiconductors, "Integrated Silicon Pressure Sensor On-Chip Signal Conditioned, Temperature Compensated and Calibrated SERIES," Time, no. 2, pp. 1-9, 2012. 